\title{
ADHESION OF ENTEROPATHOGENIC ESCHERICHIA COLI TO PIG INTESTINAL BRUSH BORDERS: THE EXISTENCE OF TWO PIG PHENOTYPES
}

\author{
R. Sellwood, R. A. Gibbons, G. W. Jones and J. M. Rutter \\ Agricultural Research Council, Institute for Research on Animal Diseases, \\ Compton, Newbury, Berkshire
}

\section{Plates XXVIII AND XXIX}

NeONATAL diarrhoea in piglets follows the proliferation of certain strains of Escherichia coli in the small intestine (Smith and Jones, 1963). These enteropathogenic strains synthesise enterotoxins which produce diarrhoea and dehydration that frequently result in the death of the piglets (Kohler, 1968; Smith and Gyles, 1970; Smith and Linggood, 1971). The rapid proliferation of $E$. coli in the small intestine appears to be attributable to the ability of the bacteria to attach themselves to the intestinal epithelium (Arbuckle, 1970; Drees and Waxler, 1970 $a$ and $b$; Bertschinger, Moon and Whipp, 1972) and thereby avoid removal from the small intestine by peristalsis (Dixon, 1960). Sojka (1965) noted that the majority of $E$. coli strains isolated from cases of neonatal piglet diarrhoea possess a surface antigen designated $\mathrm{K} 88$, and it has been shown that this antigen is an essential virulence determinant (Smith and Linggood, 1971; Jones and Rutter, 1972) apparently because it enabled K88positive $E$. coli to attach to the intestinal lining (Jones and Rutter, 1972).

To investigate the interaction between the host mucosal surface and K88positive $E$. coli a convenient test system is essential. The K88 antigen agglutinates guinea-pig red cells (Stirm et al., 1967; Jones and Rutter, 1974), and attempts to study the chemical aspects of adhesion by means of this reaction have been reported (Gibbons, Jones and Sellwood, 1975). It would have been preferable to use a natural intestinal receptor, but the technique involving adhesion of $E$. coli to disks of intestinal tissue (Jones and Rutter, 1972) is laborious. This paper describes a simple in-vitro technique that demonstrates adhesion of K88-positive $E$. coli to brush borders from pig intestinal cells; a survey of pigs in respect of the ability of their brush borders to adhere to $E$. coli is also described.

\section{MATERIALS AND METHODS}

Preparation of brush borders. Brush borders were prepared from the small intestine of pigs. The procedure was adapted from those of Miller and Crane (1961) and Evans et al. (1971). Lengths of small intestine were excised from freshly killed animals and washed free of contents with $0 \cdot 15 \mathrm{M} \mathrm{NaCl}$. The intestine was ligated and the lumen filled with a solution

Received 16 Dec. 1974; accepted 24 Jan. 1975. 
containing $0.096 \mathrm{M} \mathrm{NaCl}, 0.008 \mathrm{M} \mathrm{KH}_{2} \mathrm{PO}_{4}, 0.0056 \mathrm{M} \mathrm{Na} \mathrm{NPO}_{4}, 0.0015 \mathrm{M} \mathrm{KCl}$ and $0.01 \mathrm{M}$ ethylenediaminetetracetate(EDTA), pH 6.8 (Evans et al., 1971) until slight distension occurred. To prevent the intestine from drying externally it was immersed in a solution that was similar except that it contained $0.3 \mathrm{M}$ sucrose in place of EDTA. After incubation at room temperature for 15-20 min. the intestinal contents were discarded and the intestine was half-filled with the sucrose buffer. The epithelial cells were detached into the luminal fluid by gently rubbing the intestine between the fingers and the intestinal contents were collected. The last step of the procedure was repeated to increase the yield of cells.

All subsequent steps were performed at $4^{\circ} \mathrm{C}$. The cell suspension was centrifuged at $1200 \mathrm{~g}$ for $10 \mathrm{~min}$., the supernate was discarded, and the sedimented cells were resuspended in 10 volumes of cold $0.005 \mathrm{M}$ EDTA, $p \mathrm{H} 7.4$ (adjusted with $0.5 \mathrm{M} \mathrm{Na} \mathrm{CO}_{3}$ ) and homogenised with a Teflon-tipped tissue grinder (clearance 0.015-0.023 cm; Jencons, Hemel Hempstead) by moving the pestle up and down six times whilst it rotated at about 900 r.p.m. The homogenate was centrifuged at $300 \mathrm{~g}$ for $5 \mathrm{~min}$. and the supernate discarded. The pellet was resuspended in 10 volumes of the EDTA solution and homogenisation was repeated. The suspension was centrifuged as before and the cycle of treatments repeated until the supernate after centrifugation contained little cellular material. The brush borders were then washed twice in Krebs-Henseleit buffer, $p \mathrm{H} \mathrm{7.4}$, of the composition $0.12 \mathrm{M} \mathrm{NaCl}, 0.014 \mathrm{M} \mathrm{KCl}$, $0.025 \mathrm{M} \mathrm{NaHCO}_{3}, 0.001 \mathrm{M} \mathrm{KH}_{2} \mathrm{PO}_{4}$. The brush borders were finally filtered through glass wool and resuspended in Krebs-Henseleit buffer to a concentration of about $1 \times 10^{6}$ per $\mathrm{ml}$.

E. coli strains. A K88-positive strain W1 [0149:K91(B), K88ac(L):H10] and a K88negative mutant W1(J2) of this strain (Jones and Rutter, 1972) were used in the adhesion test. The K88-positive strain produced typical neonatal diarrhoea in conventionally reared piglets whereas strain W1(J2) did not cause disease (Jones and Rutter, 1972). Adhesion of $E$. coli strains belonging to OK groups $08: \mathrm{K} 87(\mathrm{~B}), \mathrm{K} 88 \mathrm{ab}(\mathrm{L}) ; \quad 08: \mathrm{K} 87(\mathrm{~B}), \mathrm{K} 88 \mathrm{ac}(\mathrm{L})$; O45: K" "E65”, K88ac(L); O138:K81(B),K88ac(L); O141 :K85ab(B),K88ab(L); O141:K85ab (B),K85ac(L); O147:K89(B),K88ac(L); O138:K81(B) and O141:K85ac(B) was also investigated.

The organisms were grown overnight at $37^{\circ} \mathrm{C}$ or at $18^{\circ} \mathrm{C}$ for $48 \mathrm{~h}$ in nutrient broth. The bacteria were sedimented by centrifugation at $1500 \mathrm{~g}$ for $10 \mathrm{~min}$., washed twice with KrebsHenseleit buffer, $p \mathrm{H} 7.4$ and finally resuspended in the buffer to approximately $1 \times 10^{9}$ colony-forming units per $\mathrm{ml}$.

The brush-border adhesion test. Brush-border suspension in a $0 \cdot 1-\mathrm{ml}$ volume was incubated with $0.1 \mathrm{ml}$ of bacterial suspension at room temperature in small screw-capped vials $(1 \mathrm{~cm} \times 2 \mathrm{~cm})$ with continuous gentle mixing. After $30 \mathrm{~min}$. a drop of the suspension was viewed by phase-contrast microscopy. The test was performed at room temperature and also at $4^{\circ} \mathrm{C}$ and $37^{\circ} \mathrm{C}$.

Effect of $K 88$ antisera on the adhesion test. Rabbit antisera were prepared with cell-free K88 antigen by the method of Jones and Rutter (1972). Bacterial suspensions were incubated at room temperature for $1 \mathrm{~h}$ with dilutions of rabbit antisera. Suspensions of brush borders were then added and the mixtures incubated with continuous agitation at room temperature for $30 \mathrm{~min}$. A drop of suspension was then examined by phase-contrast microscopy.

Effect of K88 antigen on adhesion. A solution of K88 was prepared from homogenates of strain W1 purified as described by Jones and Rutter (1972). Tests were carried out with suspensions of brush borders which had been previously incubated for $30 \mathrm{~min}$. at room temperature with the $\mathrm{K} 88$ antigen solution.

Adhesion of $E$. coli to tissue slices from the piglet intestine. The adhesion of the K88positive $E$. coli strain W1 and the K88-negative $E$. coli strain W1(J2) to intestinal tissue slices from gnotobiotic piglets was performed by the method of Jones and Rutter (1972).

Electron microscopy. Mixtures of brush borders and $E$. coli suspension were fixed in $2.5 \%(\mathrm{v} / \mathrm{v})$ gluteraldehyde followed by $1 \%(\mathrm{v} / \mathrm{v})$ osmium tetroxide. The pellets obtained after centrifugation were embedded in Araldite, sectioned, and stained with uranyl acetate and lead citrate. 


\section{RESULTS}

Adhesion of K88-positive E. coli to brush borders

Initial results showed that the $\mathrm{K} 88$-positive strain $\mathrm{W} 1$ readily adhered to brush borders prepared from the small intestine of young piglets (fig. 1). The K88-negative mutant W1(J2) did not adhere (fig. 2). Of the other strains tested, all the K88-positive strains adhered to the brush borders whereas none of the K88-negative strains did so. Adhesion of K88-positive $E$. coli to piglet intestinal brush borders occurred when the test was performed at room temperature and at $4^{\circ} \mathrm{C}$ and $37^{\circ} \mathrm{C}$.

$\mathrm{K} 88$-positive strains cultured at $18^{\circ} \mathrm{C}$ do not produce $\mathrm{K} 88$ antigen (Ørskov et al., 1961); such strains grown at this temperature did not adhere to brush borders.

Antisera prepared against the K88 antigen completely inhibited adhesion of K88-positive $E$. coli to brush borders; inhibition occurred at dilutions of antisera of up to 1 in 80 , but the bacteria did not agglutinate at this dilution. Antisera prepared against $\mathrm{O}$ and $\mathrm{H}$ antigens caused bacterial agglutination even in dilutions of 1 in 2560; adhesion occurred in the presence of a 1 in 10 dilution of these antisera but was slightly reduced when the bacteria were present as large agglutinated masses. These results suggest that inhibition of adhesion by K88 antisera was not attributable to bacterial agglutination.

The electronmicrograph (fig. 3) shows the close association between a K88positive bacterium and the brush-border membrane.

Survey of pigs from the Compton herd for the ability of their brush borders to adhere to K88-positive $E$. coli

Brush borders were prepared from gnotobiotic piglets aged 4 or 5 days and from conventionally reared animals aged 4-21 days or about 14 weeks. Of 177 pigs tested, 63 gave a negative result, i.e., no adhesion of K88-positive $E$. coli

\section{TABLE}

Adhesion of a K88-positive strain of Escherichia coli (WI) to brush borders prepared from piglets sired by different boars

\begin{tabular}{c|rrrrrr}
\hline \multirow{2}{*}{ Phenotype of piglets } & \multicolumn{6}{|c}{ Number of piglets sired by boar no. } \\
\cline { 2 - 7 } & $\begin{array}{rrrrrr}1 \\
(17)^{*}\end{array}$ & $\begin{array}{r}\mathbf{( 5 )} \\
+\end{array}$ & $\begin{array}{c}3 \\
(12)\end{array}$ & $\begin{array}{c}4 \\
(5)\end{array}$ & $\begin{array}{c}5 \\
(6)\end{array}$ & $\begin{array}{c}6 \\
(9)\end{array}$ \\
\cline { 2 - 7 }- & 33 & 16 & 11 & 6 & 16 & 18 \\
& 0 & 0 & 23 & 5 & 3 & 11 \\
\hline
\end{tabular}

$+=$ Brush borders capable of demonstrating adhesion; $-=$ brush borders incapable of demonstrating adhesion.

* Figures in parentheses indicate the total number of matings from which the piglets were derived. 
to their brush borders could be observed. The " negative " animals included a proportion of gnotobiotic piglets and of conventionally reared animals of all ages.

Whole litters of both gnotobiotic and of conventional piglets were also tested; some litters included both "positive" and "negative" animals whereas other litters were either completely " negative" or completely " positive ". After a large number of offspring from relatively few boars had been examined a sire effect became obvious. The table shows that all piglets sired by boars nos. 1 and 2 gave a positive result whereas boars nos. 3-6 had sired piglets of both phenotypes.

Information additional to that shown in the table emerged when the results obtained from whole litters only were considered. All piglets in a litter of 10 sired by boar no. 3 gave a negative result. A litter of 10 piglets sired by boar no. 5 contained eight "positive" and two "negative" animals. A litter of 14 piglets sired by boar no. 6 contained nine "positive" and five "negative" animals.

Adhesion of strains W1 and W1(J2) to the intestinal epithelium of the four gnotobiotic litters was evaluated by the tissue-slice test and showed good agreement with the results of the brush-border adhesion test. The piglets that gave a negative adhesion test showed a low uptake of bacteria $\left(<1 \log _{10}\right)$ in the tissue-slice test, whereas the "positive" piglets gave increases of $1.5-2.6 \log _{10}$ in the viable counts.

\section{Discussion}

The attachment of K88-positive $E$. coli to intestinal brush borders provides a convenient system to study the adhesion mechanism. The test utilises the natural receptor and is not sensitive to temperature, in contrast to the haemagglutination system described by Jones (1972) and Jones and Rutter (1974). The method of preparing brush borders was simple and gave good yields; the preparation was contaminated with $5-10 \%$ of extraneous subcellular particles, but this caused no difficulty because the appearance of brush borders under the phase-contrast microscope was highly characteristic. Adhesion was clearly seen by electron microscopy (fig. 3 ) and could be readily discerned in the light microscope (fig. 1).

The results described indicate that the adhesion observed was K88-mediated. It became apparent that the Institute pigs consisted of " positive" or " negative" animals according to the nature of their brush borders: brush borders either did or did not adhere to K88-positive E. coli.

It seems unlikely that maternally derived antibody that had become attached to the epithelial cell membrane of the piglet was associated with bacterial adhesion; a number of the neonatal animals examined had not received colostrum before slaughter and piglets in this subgroup yielded both "positive" and "negative" specimens. Since there is virtually no transfer of immunoglobulin across the placenta in the pig (Kim, Bradley and Watson, 1966; Sterzl, Rejnik and Travnicek, 1966; Porter, 1969) these animals would be devoid of any antibody. In young animals that had received colostrum, and in 
ADHESION OF E. COLI TO BRUSH BORDERS
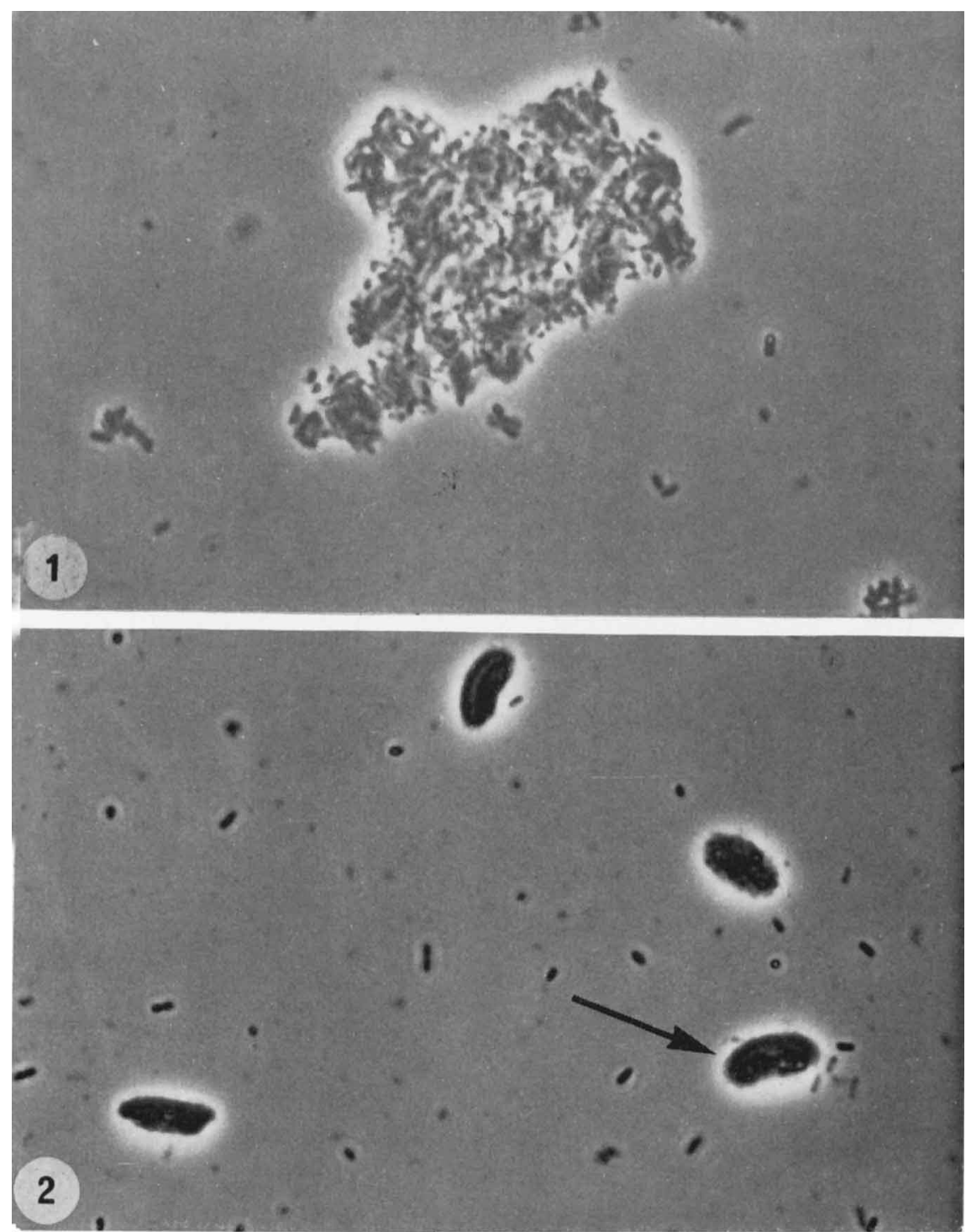

FIG. 1.-Adhesion of K88-positive Escherichia coli strain W1 to brush borders from a piglet. Phase contrast. $\times 500$.

FIG. 2.-No adhesion of K88-negative $E$. coli strain W1(J2) to brush borders (see arrow) from the same piglet as that referred to in fig. 1. Phase contrast. $\times 500$. 
ADHESION OF $E$. COLI TO BRUSH BORDERS

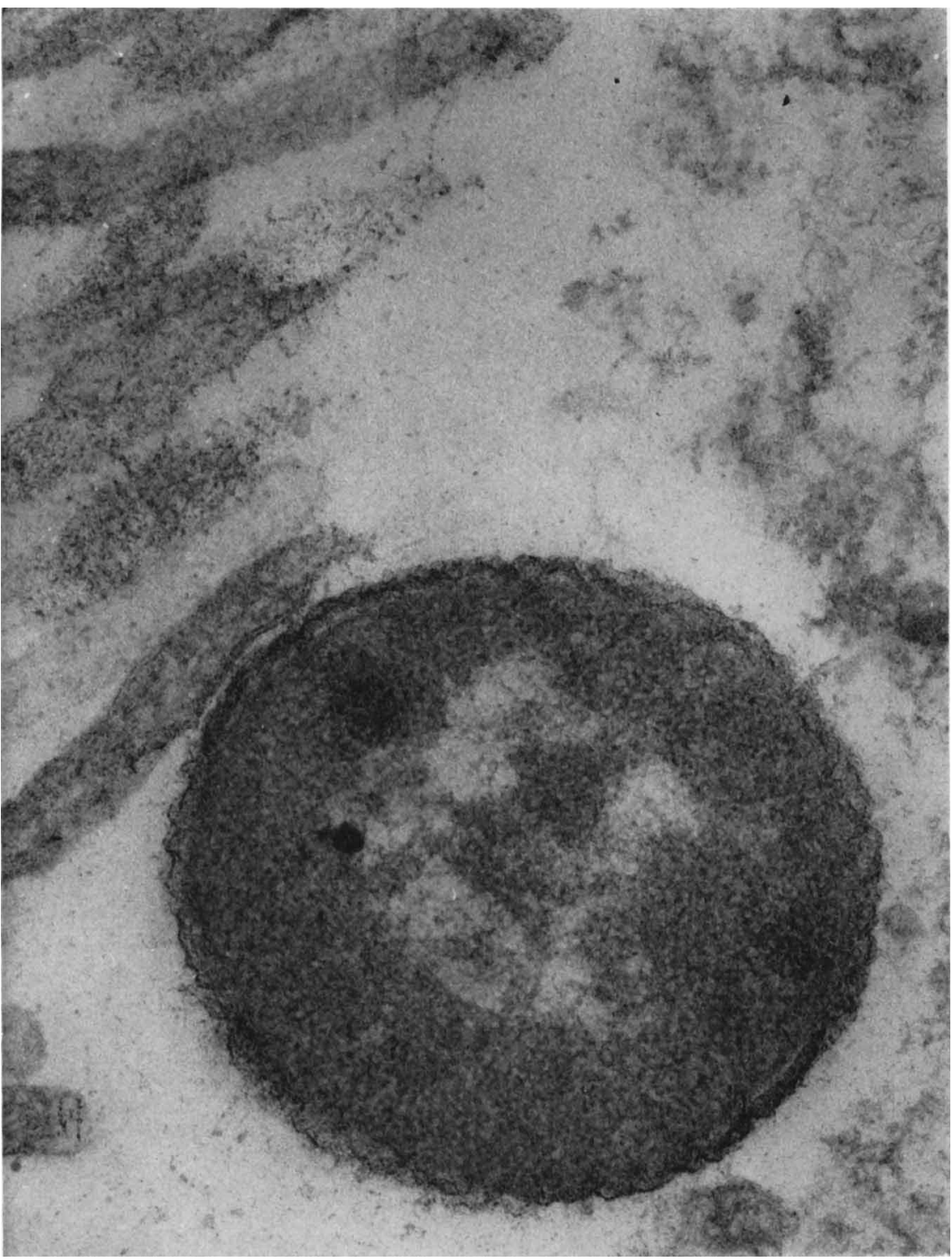

FIG. 3.-Electronmicrograph of K88-positive $E$. coli strain W1 adhering to the microvillus membrane of the brush border. $\times 110,000$. 
mature animals, the method of preparation of the brush borders would have removed any globulin not firmly associated with the cell membrane.

Of the animals examined, 114 gave positive and 63 negative tests. Fortynine offspring of boars nos. 1 and 2 were examined and, although they were the product of 22 different matings, all were " positive". Boar no. 3 , on the other hand, sired a litter in which all 10 piglets were " negative ", although this boar did sire some mixed litters in other sows. The simplest interpretation is that this represents a classical Mendelian situation of one locus with two alleles, $S$ (adhesion) dominant over $s$ (no adhesion). On this basis, boars nos. 1 and 2 would therefore be homozygous dominants (SS), boar no. 3 would be a homozygous recessive (ss) and the remaining boars, which sired both " positive" and "negative" phenotypes would be presumptive heterozygotes $(S s)$ or homozygous recessives (ss). The gene frequencies in the population so far examined would be 0.6 for $s$ and 0.4 for $S$.

Differences have been encountered in the susceptibility of piglets to both natural (Sweeney, 1968) and experimental (Rutter and Anderson, 1972) neonatal diarrhoea. It has been suggested-though not clearly demonstratedthat differences in susceptibility to $E$. coli infection are in part genetic in origin (Wijeratne, Crossman and Gould, 1970). The strong inference that the differences reported here are genetically controlled presumably implies the presence or absence of a specific K88 receptor on the epithelial cell surface of the animal. This observation provides a possible explanation for the differences in susceptibility, and the results of adhesion tests on the surviving piglets of two litters from infection experiments with strain W1 provide some support for this view (Rutter, Burrows and Sellwood, unpublished observation).

Experiments are now in progress to ascertain whether pigs of known genotype can be bred as predicted by the genetic system described and also to determine whether the " negative" phenotype, as shown by failure of K88positive $E$. coli to adhere to the brush borders, is correlated with resistance of the piglet to infection by these organisms. It seems likely that pigs that are significantly more resistant or more susceptible to neonatal $E$. coli infection than the general pig population could be bred, and this should greatly simplify future investigation of host-pathogen relationships. It would also help to elucidate the interaction between heredity and environment in the pathogenesis of the disease.

\section{SUMMARY}

An in-vitro test that demonstrates adhesion of K88-positive Escherichia coli to brush borders prepared from the small intestine of the pig is described. K88-positive E. coli adhered to the brush borders from some pigs (" positive" pigs) but not others (" negative" pigs). The sires of the pigs tested could be placed into two groups, namely, those that sired only " positive" piglets, and those that sired a mixture of " positive " and " negative " piglets. The incidence of the two phenotypes in litters indicated that "positive" and "negative" piglets arose as a result of simple Mendelian inheritance. It is suggested that 
" negative" pigs could be bred and that they might have a natural resistance to neonatal infection with K88-positive $E$. coli.

We thank Mrs M. Hoare, Mr C. Davies and Mr M. Dennis for providing the gnotobiotic litters, Mrs P. Bland for the electronmicrographs and Mr I. Jebbett for the photographs. We are also grateful to $\mathrm{Mr} \mathrm{M}$. Burrows for the preparation of cultures and to $\mathrm{Mr} \mathrm{T}$. Brown, Miss J. Knight and Miss J. Manning for technical assistance.

\section{REFERENCES}

ARBuCKLE, J. B. R. 1970. The location of Escherichia coli in the pig intestine. J. med. Microbiol., 3, 333.

Bertschinger, H. U., MoON, H. W. AND WhIPP, S. C. 1972. Association of Escherichia coli with the small intestinal epithelium. I. Comparison of enteropathogenic and nonenteropathogenic porcine strains in pigs. Infect. Immun., 5, 595.

Dixon, J. M. S. 1960. The fate of bacteria in the small intestine. J. Path. Bact., 79, 131.

Drees, D. T. AND WAXLER, G. L. 1970a. Enteric colibacillosis in gnotobiotic swine: a fluorescent microscopic study. Am. J. vet. Res., 31, 1147.

Drees, D. T. AND WaXLeR, G. L. 1970 b. Enteric colibacillosis in gnotobiotic swine: an electron microscopic study. Am. J. vet. Res., 31, 1159.

Evans, E. M., Wrigglesworth, J. M., Burdett, K. AND Pover, W. F. R. 1971. Studies on epithelial cells isolated from guinea pig small intestine. J. Cell Biol., 51, 452.

Gibbons, R. A., JoNes, G. W. AND SellwoOd, R. 1975. An attempt to identify the intestinal receptor for the $\mathrm{K} 88$ adhesin by means of a haemagglutination inhibition test using glycoproteins and fractions from sow colostrum. J. gen. Microbiol., 86, 228.

JONES, G. W. 1972. The adhesive properties of K88-antigen of strains of Escherichia coli pathogenic to neonatal pigs. Ph.D. Thesis, University of Reading.

Jones, G. W. AND RuTter, J. M. 1972. Role of the K88 antigen in the pathogenesis of neonatal diarrhoea caused by Escherichia coli in piglets. Infect. Immun., 6, 918.

JoNes, G. W. AND RutTER, J. M. 1974. The association of K88 antigen with haemagglutinating activity in porcine strains of Escherichia coli. J. gen. Microbiol., 84, 135.

Kim, Y. B., BRadley, S. G. AND Watson, D. W. 1966. Ontogeny of the immune response. I. Development of immunoglobulins in germfree and conventional colostrum-deprived piglets. J. Immun., 97, 52.

KOHLER, E. M. 1968. Enterotoxic activity of filtrates of Escherichia coli in young pigs. Am. J. vet. Res., 29, 2263.

Miller, D. AND CRANE, R. K. 1961. The digestive function of the epithelium of the small intestine. II. Localization of disaccharide hydrolysis in the isolated brush border portion of intestinal epithelial cells. Biochim. biophys. acta., 52, 293.

ØrSKov, I., ØRSKOV, F., SOJKA, W. J. AND LEACH, J. M. 1961. Simultaneous occurrence of Escherichia coli B and L antigens in strains from diseased swine. Acta path. microbiol. scand., 53, 404.

PORTER, P. 1969. Transfer of immunoglobulins IgG, IgA and IgM to lacteal secretions in the parturient sow and their absorption by the neonatal piglet. Biochim. biophys. acta, 181, 381.

RUtTer, J. M. AND ANDERson, J. C. 1972. Experimental neonatal diarrhoea caused by an enteropathogenic strain of Escherichia coli in piglets: a study of the disease and the effect of vaccinating the dam. J. med. Microbiol., 5, 197.

Smrth, H. W. AND GyLES, C. L. 1970. The relationship between two apparently different enterotoxins produced by enteropathogenic strains of Escherichia coli of porcine origin. J. med. Microbiol., 3, 387.

SMITH, H. W. AND JONES, J. E. T. 1963 . Observations on the alimentary tract and its bacterial flora in healthy and diseased pigs. J. Path. Bact., 86, 387.

Smrth, H. W. AND LINGGOOD, M. A. 1971. Observations on the pathogenic properties of the K88, Hly and Ent plasmids of Escherichia coli with particular reference to porcine diarrhoea. J. med. Microbiol., 4, 467. 
SoJKA, W. J. 1965. Escherichia coli in domestic animals and poultry. Review Series no. 7, Commonwealth Bureau of Animal Health, Farnham Royal.

Sterzl, J., REJNIK, J. AND TRAVNICEK, J. 1966. Impermeability of pig placenta for antibodies. Folia microbiol., 11, 7.

STIRM, S., ØRSKOV, F., ØrSKov, I. AND BIRCH-ANDERSEN, A. 1967. Episome carried surface antigen K88 of Escherichia coli. III. Morphology. J. Bact., 93, 740.

SWEENEY, E. J. 1968. Escherichia coli in enteric disease of swine: observations on herd resistance. Ir. vet. J., $22,42$.

Wijeratne, W. V. S., Crossman, P. J. and Gould, C. M. 1970. Evidence of sire effect on piglet mortality. Br. vet. J., 126, 94. 